\title{
THE DEVELOPMENT OF THE MARKET OF THE PRODUCTION OF WIND ENERGY IN POLAND AND SELECTED EU COUNTRIES
}

\author{
Grzegorz BIERNACKI, Małgorzata SMYK, Sandra DOBOSZ, \\ Dalia GÓRSKA, Patrycja MUSIAŁOWSKA \\ University of Zielona Góra \\ Karolina MATERNE \\ Universität Potsdam
}

\begin{abstract}
:
The paper discusses the problem of renewable energy sources, with particular focus put on wind energy. Special attention is paid to the development of this sector of production in Poland and selected UE countries in the recent years. Furthermore, selected legal acts and strategic document regulating the wind production market in Poland are pre4sented. At the same time the development potential of this are of energy production in Poland is discussed.
\end{abstract}

Key words: renewable energy sources, wind energy production, energy production market, energy production

\section{INTRODUCTION}

The development of civilization and modern technology constitutes an enormous success in the history of humanity, yet the results of these changes exert negative impact on the natural environment which forms the basis of human existence. The natural environment consist of animate and inanimate elements which surround living creatures and to a large extent depend on one another. The elements of the natural environment include above all living organisms, soil, topographic profile, climate, hydrographic conditions and geological formation [2]. Initially the major threat to the natural environment consisted in the of the occurrence of pollution from Volcano eruptions, erosion of rocks, or fire resulting from long-term droughts. At present however, the natural environment is endangered by anthropological threats resulting from the development of human civilization, and in particular the development of the of the sector of production of energy on the basis of conventional sources [4]. This sector and its development related with the increasing demand and for energy in result of the expansion of cities or industrial center, which significantly contribute to the growth in the emission of carbon dioxide into the atmosphere, exert a multidimensional impact on the natural environment. The diagram below (Fig. 1) shows that between the years 1880 and 2014 the level of emission reached 33 billion $\mathrm{Mg}$.

The process results in the occurrence of greenhouse effect, acid rain and other irreversible phenomena. Renewable energy sources (RES) may constitute a solution which in future could lead to the decrease of the pollution of the environment and improve the condition of the natural environment and the quality of life on the Earth.

Background literature as well as experience of developed economies of EU countries, indicate that production of wind energy production constitutes a dynamically develo- ping instrument for solving such problems. That is why the paper discusses selected problems of this sector of energy production.

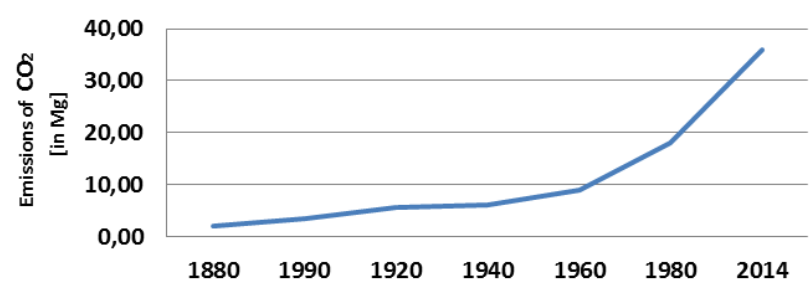

Fig. 1 The growth of the emission of $\mathrm{CO} 2$ in the world and EU [in $\mathrm{Mg}$ ]

Source: based on [18].

\section{RES AND WIND ENERGY - HISTORICAL OUTLINE}

With the significant increase in the threat to the natural environment as well its consequences, people wish to reduce the impact of harmful substances on the environment by means of use of natural energy sources. In Poland in 2014 the share of energy from renewable sources in the production of electric energy reached the level of $11 \%$ [19]. The characteristics of particular types of RES constitutes an important element of the analysis. Biomass from organic matter, which undergoes biodegradation, is the oldest form, and its share in the fuel balance both in Poland and in the world increases significantly in view of efficiency and application. RES includes also: energy from wood, straw, gas from active landfills, gas from fermentation of deposits and sewage, bio-fuel and bio-gas from agricultural bio-gas plants. Solar energy production, used in Poland mainly for heating domestic water, seems to be the most dynamically developing branch of energy production based on renewable sources. Unfortunately $100 \%$ use of solar energy is not 
possible due to uneven distribution of solar radiation throughout the year.

Geothermal energy is another form of RES, obtained by means of bore holes into which cool water is pumped and heated to high temperature by hot rocks. Wind energy based on the use of wind power propelling turbines is also highly efficient and its production does not result in the emission of greenhouse gases [8]. Solar energy also plays a significant role in the world, whereas other forms of the production of renewable energy are developing dynamically and popularized by various institutions whose aim is to reduce the emission of $\mathrm{CO}_{2}$.

Throughout history, people have always been interested in wind energy. In the past windmills were used for grinding grain or pumping water. In the ancient Egypt wind was used as a mechanism propelling boats. In India wind energy was used for the purpose of irrigation by means of special windlasses. Charles F. Brush built the first wind power plant in 1888. In 1950 wind energy was used as a generator of alternating current, and later on wind turbines were located on the coast of Gedser in Denmark, where for numerous years they were used as tools for research on the development of new technologies. With the development of the market, gradually mass production of wind energy facilities started and $B+R$ processes focusing on improvement of wind turbines were initiated. Both complicated automatics as well as generators themselves underwent revolution.

Developments in electronics or material engineering exerted enormous impact on wind energy production industry, and new, more efficient and reliable products appeared on the market. This included turbines wth up to $1 \mathrm{MW}$ Power. At present wind farms produce up to $4.5 \mathrm{MW}$ Power [12]. Relatively recently, since 1990 s a significant development of wind farms can be observed. The first wind farm in Poland was constructed in 1991 in Lisew in the Pomorskie province, whereas another one a few years later in Rytr and it was a prototype named EW100-22-20 NOWOMAG. In comparison with the European Union countries, in Poland the potential of wind energy is underestimated despite its merits. The most significant include elimination of pollution emitted to the atmosphere and renewable energy resource. Furthermore small turbines can be used and located in places where electric al energy is not supplied in a traditional way. Wind turbines perfectly fit the seaside and not spoil the landscape. Production of wind energy has also its drawbacks. The strength of the wind varies depending on the latitude and the propelling power may be smaller. Large wind farms pose a threat to birds and degrade their natural habitats. Apart from producing electric energy, wind turbines generate noise, which means that they must located at the minimum distance of $200 \mathrm{~m}$ from estates [13]. Wind energy does not affect the degradation of the natural environment and hence guarantees ecological security for future generations.

\section{REVIEW OF SELECTED LEGAL ACTS AND STRTEGIC DOCUMENTS RELATED TO THE POLISH RES SECTOR}

The most important laws and legal acts related to the functioning of the Polish RES sector include:

- the Act on energy law of April 10 ${ }^{\text {th }}, 1997$ with further amendments and secondary regulations i.e. the Regulation of the Minister of economy, Labor and social policy of May 30th, 2003.
- the Act on bio-components used in liquid fuel and liquid bio-fuel of October $2^{\text {nd }}$, Winding from January 2004, along with secondary regulations i.e. the Regulation of the Council of Ministers of January 10th, 2004 on the minimum amount of bio-components introduced into the market in liquid fuel or liquid biofuel,

- the resolution of the Parliament on the development of the production of renewable energy of July $08^{\text {th }}$, 1999.

On the basis of the above Resolution two important government documents were developed:

1. 'The Strategy of the Development of „Renewable Energy",

2. The State Ecological Policy which were approved by the Parliament on 22.08.2001 [8].

Wind energy provides $2 \%$ of electric Power in the Word. It is becoming a leader in respect of renewable energy, yet it has to be stressed that it is still in the chase of development. Figure 2 shows the data concerning the production of this type of energy in Poland and selected EU countries in 2009.

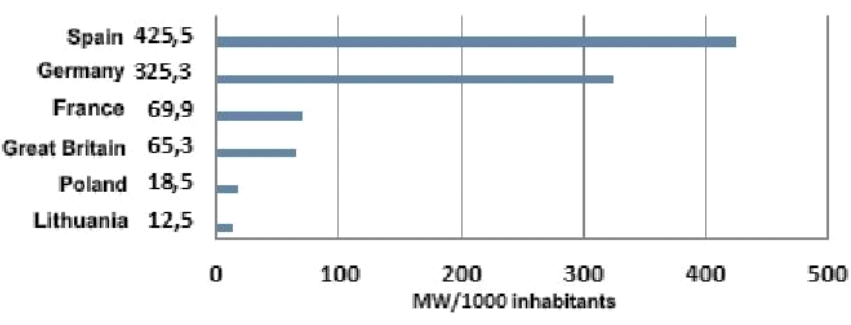

Fig. 2 Production of wind energy in Poland and selected EU countries in 2009

Source: developed on the basis of [6].

Along with the changes in the EU policy concerning RES a New directive 201/77/EC was introduced which applied to gradual increase of the share of unconventional sources in the production of electric and heat energy. The project had a priority status in Poland since it was linked with the development of new technologies, reduction of harmful emissions, development of the labor market and the financial support from EU in the future years.

Polish authorities revolutionized previous legal conditions and finally created a complex strategy for the realization of tasks related to production of energy from renewable resources: "The assumptions of Polish energy policy until 2020" approved in 2000 by the Economic Committee of the Council of Ministers [1].

According to the forecast in Poland $15 \%$ of the demand for electric energy will be generated from renewable resources. This indicates at the development in the sector of wind energy.

Despite the introduction of new directives concerning further amendment of the Act on energy law, administrative and legal actions are not supported by the financial and investment policy of the state, which exert impact on failure to meet the obligations in respect of protection of the climate. Development of the production of wind energy, among others, constitutes a significant instrument of the realization of these obligations.

Figure 3 shows the planned increase of the power of wind farms in Poland until 2020. 


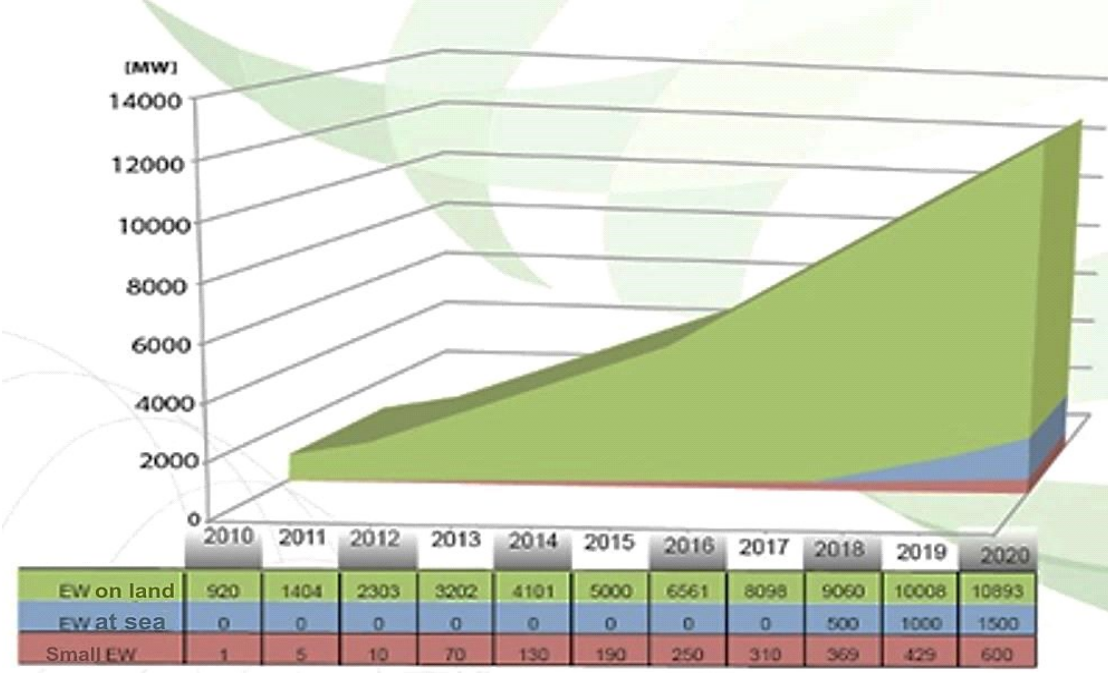

Fig. 3 The increase in the power of wind farms in Poland up to 2020 Source: [21].

\section{THE POTENTIAL AND DEVELOPMENT OF WIND ENERGY IN POLAND AND SELECTED EU COUNTRIES}

The measurement of wind energy in Poland is performer by IMiGW (The Institute of Meteorology and Water Management). On the basis of the data collected for at least one year a wind, presented in Fig. 4 was developed [7].

It can be observed that 5 areas of varied potential of wind power were determined. The map shows that approximately $40 \%$ of the area of Poland demonstrates favorable conditions for the development of wind farms, and in particular in the north of the country. Wind power is used by increasingly more wind farms in particular provinces. Figure 5 shows the allocation of their power in 2010 on the territory of Poland [20].

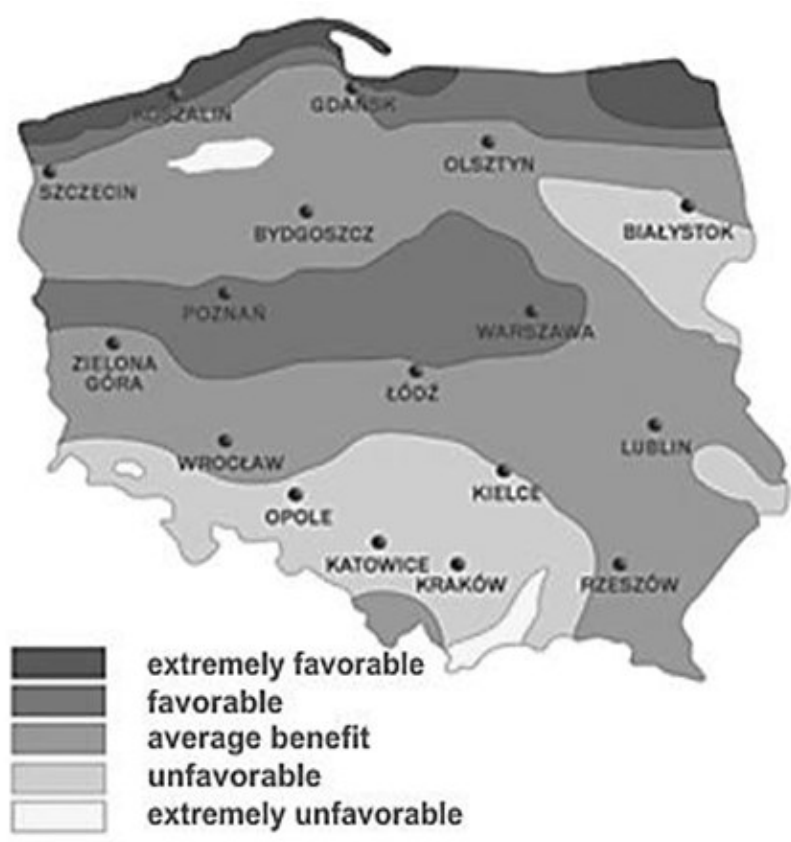

Fig. 4 Wind map of Poland Source: [10].

At the same time table 1 presents the most import ant (the biggest) wind farms on the territory of the Republic of Poland.

Wind farms process wind energy into mechanical energy which in turn is converted into electric energy.

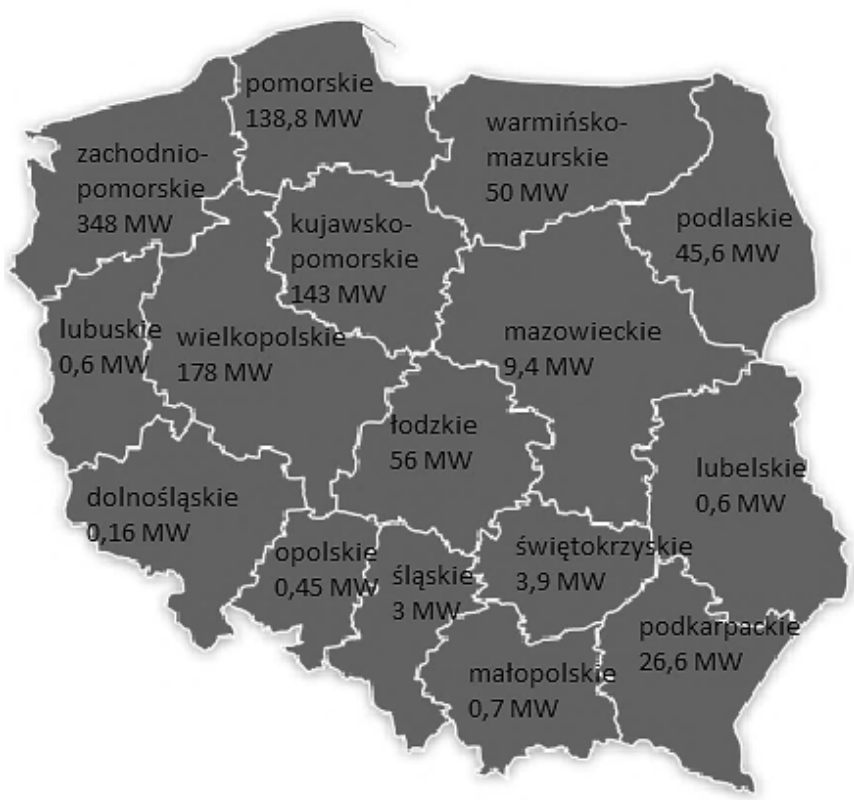

Fig. 5 The allocation of wind energy power in particular provinces in Poland State as of 31.06.2010 Source: [16].

Table 1 Main wind farms in Poland

\begin{tabular}{lll}
\hline \multicolumn{1}{c}{ LOCATION } & \multicolumn{1}{c}{ PROVINCE } & \multicolumn{1}{c}{ POWER } \\
\hline Brzozowice & zachodniopomorskie & $5,1 \mathrm{MW}$ \\
Cisowo & zachodniopomorskie & $18 \mathrm{MW}$ \\
Zagórze & zachodniopomorskie & $30 \mathrm{MW}$ \\
Lisewo & pomorskie & $10,8 \mathrm{MW}$ \\
Tymień & zachodniopomorskie & $50 \mathrm{MW}$ \\
Puck & pomorskie & $22 \mathrm{MW}$ \\
Kisielice & warmińsko-mazurskie & $40,5 \mathrm{MW}$ \\
Kamieńsk & łódzkie & $30 \mathrm{MW}$ \\
Jagniątkowo & zachodniopomorskie & $30,6 \mathrm{MW}$ \\
Gnieżdżewo & pomorskie & $22 \mathrm{MW}$ \\
Karścino & zachodniopomorskie & $69 \mathrm{MW}$ \\
Łebcz & pomorskie & $8 \mathrm{MW}$ \\
Suwałki & podlaskie & $41,4 \mathrm{MW}$ \\
\hline
\end{tabular}

Source: [5]. 
These are high-speed wind turbines with horizontal axis. Three blade rotor with automatically adjusted blades of appropriately selected profile propelled by means of a gearbox an asynchronic or synchronic generator. The operation of wind farms is electronically controlled. In simple words it can be said that it operates automatically with no need for supervision. In case of failure, a computer stops operation and signals the condition. The turbine is propelled by wind energy. It is one of inexhaustible resources of energy since wind is a permanent phenomenon in nature, thanks to the sun. Wind can be characterized by two features: speed and repeatability. The speed of wind is smallest close to the ground.

It increases with altitude. Wind turbines are located AT the height from a dozen to one hundred meters. The minimum speed constitutes a limit since it is required for the maintenance of appropriate torque. The maximum speed also constitutes a limit since if it is too high, the maximum torque is exceeded which may lead to a mechanical damage of the rotor. The number of hours when wind blows at a certain speed throughout the year is referred to as repeatability. This index is decisive while deciding whether the construction of the wind farm is cost effective. Long term meteorological measurements constitute the basis for the calculation of the energetic resources of the wind. Regional energetic resources are calculated at first, and then regional estimates are performed.

Wind energy is a non-emission technology - i.e. Turing operations id does not emit greenhouse gases or dust into the atmosphere. Wind farms do not generate hazardous waste, it does not degrade or pollute soil and does not result in losses in water circulation [3]. Considering the energy put into the production, operation and utilization of particular elements, wind farms are one of the most advantageous energy production technologies preventing changes of the climate. On the basis research of Ryszard Ingielewicz $\mathrm{PhD}$ and Adam Zagubień PhD from Koszalin Technical University who measured and analyzed acoustic phenomena on a farm located in the Pomeranian region, it was obse- rved that the operations of wind farms does not generate infra-sounds at the level which could constitute hazard to human health. Depending on the construction, the following types of wind turbines are distinguished:

- Horizontal Axis Wind Turbine - HAWT,

- Vertical Axis Wind Turbine - VAWT.

Apart from the division depending on construction, wind farms are classified according to the amount of generated power:

- low power installation which can supply individual facilities,

- wind turbines of the power up to 50kW used for instance for supplying households,

- wind farms with power above 100kW which usually connected to the energy grid.

Additionally wind farms can be divided into those supply, in part or totally energy grid, and those which operate in separate networks. In the latter case they are used e.g. for charging batteries or as sources supplying heating systems [22].

According to the Institute of Meteorology and Water Management, in Poland tere are favorable conditions for construction of wind farms. The best regions are:

- coast line between Koszalin and Hel,

- Suwałki region,

- central Wielkopolska and Mazowsze,

- Beskid Śląsk and Beskid Żywiecki,

- Bieszczady and Pogórze Dynowskie [16].

The analysis show that in 2010 most wind farms are located in northern Poland, and in particular in the provinces of wielkopolskie and kujawsko-pomorskie.

In 2011 Germany, Spain, France, Italy and Great Britain had the biggest installed power in wind farms. This means that in these countries wind energy production is developing dynamically. Denmark, Swede, Holland and Ireland also have good conditions for the development of wind farms. The smallest installed power is in Lithuania, Slovakia, Switzerland and Luxemburg [14]. Figure 6 presents the location of wind farms in Europe .

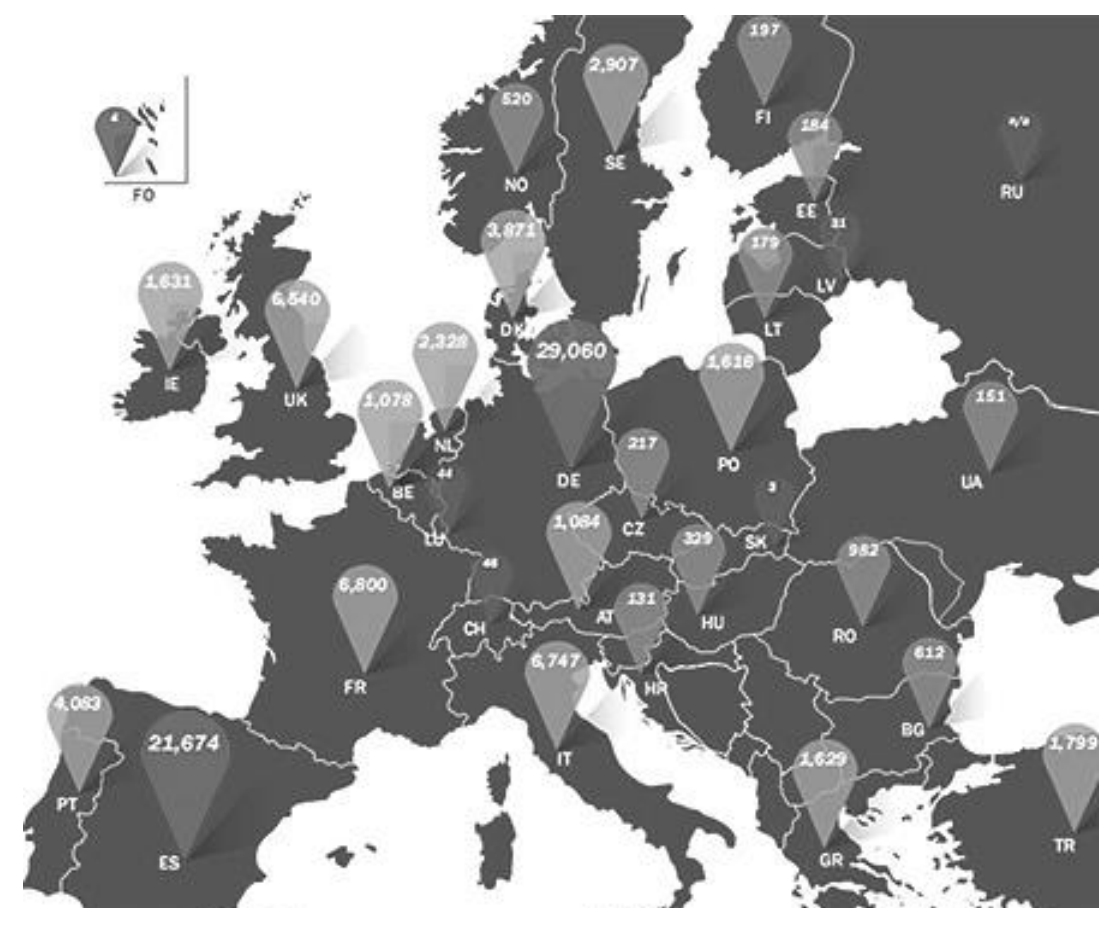

Fig. 6 The location of wind farms in Europe

Source: [17]. 


\section{CONCLUSIONS}

The paper discusses selected aspects of the market of wind energy production in Poland and other EU countries. At present energy occupies a high position among various forms of generation of energy from alternative sources and the production market is developing dynamically. Germany, France, Great Britain and Holland are leaders in this respect [6]. In these countries the development of this sector has been the fastest in recent years. The paper shows that Poland is not one of the leaders in the production of wind energy despite certain potential for development, especially in the northern and central regions of the country. This is confirmed by a comparative analysis of the use of wind energy in Poland and selected EU countries.

In general, in medium developer economies, such as Poland, dynamic development of this sector of production is hindered, among others by high cost of investment, unstable political situation, lack sufficient resources for market stimulation and protests of local communities.

The European Committee indicates that wind energy has low cost intensity and is more available in comparison with the production of renewable energy from other resources. The forecasts developed in EU indicate that by 2020 wind farms may become competitive with nuclear plants in Europe. The EU Committee stresses that in view of a short period of construction and the fact that the facilities may be located on waste land and fill unused space or areas which are not populated, wind energy may constitute one of the pillars of the development of energy production sector in the near future. This potential should be used, and Poland ought to join the EU leaders, which may improve the energy balance in the country, but also exert a positive effect on the condition of the environment as well costs of energy production and consumption.

\section{REFERENCES}

[1] T. Boczar, Wykorzystanie energii wiatru, Wydawnictwo PAK, Warszawa 2010.

[2] J. Bogdanienko, Odnawialne źródła energii, Biblioteka Problemów, t. 290, Wyd. PWN, Warszawa, 1989 rok, s. 26-48.

[3] A. Chochowski, F. Krawiec, Zarzqdzanie w energetyce, Wydawnictwo Difin, Warszawa, 2008, s. 255-260.

[4] W. Ciechanowicz, Energia, środowisko, ekonomia. Wydawnictwo Inst. Badań Systemowych PAN, Warszawa, 1997.
[5] P. Dąbrowski, Potencjat OZE w Polsce. [Online]. Available: www.mojeopinie.pl/

[6] J. Gronowicz, Niekonwencjonalne źródła energii, Wydawnictwo Instytut Technologii PIB, Radom-Poznań 2010.

[7] B. Kołodziej. M. Matyka, Odnawialne źródła energii. Rolnicze surowce energetyczne. Wydawnictwo PWRiL, Poznań 2012.

[8] W.M. Lewandowski. Proekologiczne odnawialne źródła energii, Wydawnictwo IV, Wydawnictwo WNT, Warszawa, 2012, s. 65-75, s. 98.

[9] [Online]. Available: www.domrel.pl

[10] [Online]. Available: www.polenergia.pl/pol/pl/strona/ otoczenie.

[11] [Online]. Available: http://slideplayer.pl

[12] [Online]. Available: www.zasoby1.open.agh.edu.pl

[13] [Online]. Available: www.zielonaenergia.eco.pl

[14] Opracowanie PSEW na podstawie danych URE. Rozmieszczenie mocy $w$ energetyce wiatrowej $w$ poszczególnych województwach Polski. Stan na 31.06.2010. [Online]. Available: www.elektrowniewioatrowe.org.pl

[15] Polskie Stowarzyszenie Energetyki Wiatrowej, Raport: Wizja rozwoju energetyki wiatrowej w Polsce do 2020. [Online]. Available: www.consus.eu/

[16] J. Radziewicz, Wykorzystanie energii wiatrowej w Polsce. Rolniczy Magazyn Elektroniczny [Online]. Available: www.cbr.edu.pl/

[17] Rozwój energetyki wiatrowej w Polsce w kontekście planów przekształcenia polskiej gospodarki z wysokoemisyjnej na niskoemisyjnq, [Online]. Available: www.msp.gov.pl/pl

[18] S.M. Szukalski, S. Malinowski, (red.), Energia Odnawialna. Technologia, ekonomia, finansowanie. Wydawnictwo WING, Poddębnice, 2013.

[19] R. Tytko. Urzqdzenia i systemy energetyki odnawialnej, Wyd. VI, Wydawnictwo Towarzystwo Słowaków w Polsce, Kraków, 2015, s. 19-51.

[20] R. Tytko. Odnawialne źródła energii, Wydawnictwo OWG, Warszawa, 2009

[21] Ustawa OZE. Nowa ustawa o OZE sprzyja zielonej energii. [Online]. Available: www.ekologia.pl/

[22] Zbuduj elektrownię wiatrowq! [Online]. Available: http://automatykab2b.pl/

Grzegorz Biernacki, Małgorzata Smyk, Sandra Dobosz,

Dalia Górska, Patrycja Musiałowska

University of Zielona Góra

"Eco-Management" Student Research Club

ul. Podgórna 50, budynek A-0, 65-246 Zielona Góra, POLAND

e-mail: Grzegorz.biernacki00@wp.pl; malgorzata.smyk93@wp.pl

Sandra_Dobosz@wp.pl,gorskadalia@gmail.com,

musialoska.patrycja@o2.pl

Karolina Materne

Universität Potsdam, GERMANY

e-mail: karo.materne@yahoo.de

Artykuł w polskiej wersji językowej dostępny na stronie internetowej czasopisma.
The article in Polish language version available on the website of the journal 